\title{
KONSEP KECUKUPAN BAHAN PANGAN PERSPEKTIF ISLAM
}

\author{
KASLAM \\ Fakultas Ushuluddin, Filsafat Dan Politik UIN Alauddin \\ Makassar, Indonesia \\ Email: etos.kaslam@uin-alauddin.ac.id
}

\section{Abstrak}

The concept of food sufficiency is an important matter and has been regulated in Islam. This article will examine the proposition that discusses methods for managing food supplies, from production to distribution to consumption patterns. Food becomes insufficient when there is an error in producing. The method of managing agricultural land is also regulated in Islam. Although food has been produced sufficiently, but the pattern of distribution is not evenly distributed will also affect the level of food sufficiency for the community. Distribution must be uniform and patterned so that it is sufficient for everyone. If the production and distribution of food is safe, but the consumption pattern has not adopted Islamic principles, then the available food will not be sufficient. The pattern of consumption that is not excessive and not wasteful is one of the things regulated in Islam. Therefore these three aspects must go well on the guidance of the Qur'an and Hadith.

\section{Keywords}

Bahan Pangan, Produksi, Distribusi, Konsumsi

\section{Pendahuluan}

Jumlah penduduk dunia terus meningkat. Worldometers mendata jumlah penduduk dunia telah mencapai angka 7,7 miliar jiwa pada tahun 2019. Dibandingkan pada tahun 2018, angkanya sebesar 7,6 miliar jiwa, sehingga mengalami kenaikan sebesar 1,08\%. Selama sepuluh tahun terakhir, 
jumlah penduduk dunia terus mengalami peningkatan yang stabil pada kisaran angka pertumbuhan 1 - 1,2 \% per tahun. Meskipun demikian, data pertumbuhan penduduk dunia ini menunjukkan trend yang sangat melambat. Pada tahun 2050 diprediksi pertumbuhan penduduk didunia hanya berkisar diangka 0,53\%.

Berdasarkan peta regional dunia, Asia menjadi wilayah di dunia dengan jumlah penduduk yang tertinggi, yaitu sebanyak 4,6 miliar jiwa. Afrika kemudian menyusul dengan sebanyak 1,3 miliar dan kemudian Eropa sebanyak 747,2 juta jiwa. Sementara berdasarkan Negara, Negara dengan jumlah penduduk terbanyak diduduki oleh Republik Rakyat Tiongkok sebanyak 1,43 miliar jiwa, diurutan kedua, India sebanyak 1,37 miliar jiwa, Amerika Serikat sebanyak 329 juta jiwa dan di posisi keempat ditempati oleh Indonesia dengan penduduk sebanyak 270,6 juta jiwa.

Pertumbuhan penduduk yang tinggi tantangan tersendiri disetiap Negara untuk menyediakan bahan pangan ${ }^{1}$ bagi rakyatnya, tak terkecuali Indonesia. Indonesia sebagai Negara berkembang ${ }^{2}$ Setiap tahun, jumlah penduduk Indonesia mengalami peningkatan sebesar 3,7 hingga 4 juta jiwa. Hal ini berarti bahwa kebutuhan pangan bagi penduduk juga semakin besar. Di satu sisi Indonesia merupakan negara agraris terbesar di dunia dan pertanian menjadi sumber mata pencaharian yang paling banyak ditemui, dan mengalami banyak kendala seperti

\footnotetext{
${ }^{1}$ Pangan adalah segala sesuatu yang berasal dari sumber hayati dan air, baik yang diolah maupun tidak, diperuntukkan sebagai makanan dan minuman bagi konsumsi manusia, termasuk bahan tambahan pangan, bahan baku pangan dan bahan lain yang digunakan dalam proses penyiapan , pengolahan, atau pembuatan makanan dan minuman (Peraturan Menteri Pertanian No. 25/Permentan/OT.140/2/2010)

2 Negara berkembang memiliki ciri-ciri (1) standar kehidupan rendah; (2) tingkat pendapatan yang rendah; (3) produktivitas rendah; (4) angka beban ketergantungan yang tinggi; (5) angka pertumbuhan penduduk tinggi; (6) besarnya pengangguran; (7) ketergantungan pada sector pertanian dan ekspor produk primer.
}

TAHDIS Volume 10 Nomor 2 Tahun 2019 
persoalan gagal panen. Persoalan ini semakin kompleks dengan semakin berkurangnya lahan pertanian produktif yang bisa diusahakan oleh petani untuk memproduksi bahan pangan, selain karena wilayahnya semakin berkurang akibat pembangunan pemukiman, juga karena ketertarikan generasi muda untuk berprofesi sebagai petani juga sangat rendah. Jika hal ini terus menerus terjadi, maka cepat atau lambat, kelangkaan bahan pangan akan terjadi dan penduduk akan mengalami kesulitan untuk mengakses bahan pangan yang dapat berujung pada bencana kelaparan. Produksi bahan pangan dalam bidang pertanian perlu menjadi perhatian serius untuk segera ditangani.

Islam sebagai rahmatan lil alamiin telah memberikan pedoman yang jelas tentang bagaimana mengelolah pertanian untuk kemakmuran dalam sebuah masyarakat. Didalam Al Qur'an, terdapat banyak dalil yang membahas dan menerangkan tentang pertanian dalam arti luas - termasuk diantaranya adalah perkebunan, peternakan dan juga pengelolaan proses serta penggunaan hasilnya. Diharapkan ini menjadi panduan hidup yang dapat digunakan dalam menangani produktivitas pertanian demi menunjang ketersediaan bahan pangan bagi masyarakat. Permasalahan pangan, sebenarnya bukanlah terletak dari tinggi atau rendahnya daya beli. Mereka yang memiliki daya beli yang tinggi, diperhadapkan pada masalah bahwa barang yang ingin dibeli tidak tersedia dengan baik. Sedangkan mereka yang memiliki daya beli yang rendah, walaupun barang yang ingin dibeli tersedia cukup, tetapi tidak memiliki kemampuan beli, juga menjadi masalah. Oleh karena itu, dua hal yang harus menjadi perhatian adalah adanya bahan pangan yang mencukupi sekaligus terjangkau untuk mendapatkannya. 
Bahan pangan yang tersedia cukup bagi masyarakat, khususnya keluarga, merupakan kebutuhan dasar untuk keberlanjutan hidup. Namun, sebagai seorang muslim, makan dan minum bukanlah tujuan utama atau demi memenuhi nafsu belaka, tetapi hanyalah sarana untuk menjaga kesehatan tubuh agar mampu beribadah dengan baik kepada Allah swt. Apabila kebutuhan telah terpenuhi, maka tidak perlu berlebih-lebihan, karena bisa menjadi sumber penyakit dan kemungkinan mengurangi atau mengambil bagian dari orang lain. Allah Swt berfirman :

Artinya:

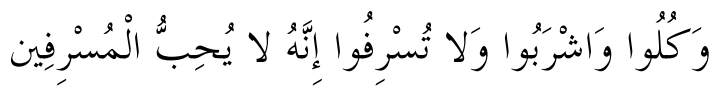

"Makan dan minumlah kamu, dan jangan berlebihan. Sesungguhnya Allah tidak menyukai orang-orang yang berlebihan (QS. Al Ar'af: 31)"

Selama persediaan bahan pangan dipergunakan sebagaimana mestinya, maka pasti mencukupi kebutuhan bahan pangan seluruh umat manusia. Dengan demikian, produktifitas pertanian bagaimana seharusnya diterapkan?, bagaimana pula konsep persediaan bahan pangan yang baik agar dapat tercukupi kebutuhan seluruh umat manusia? Serta bagaimana pola konsumsi yang baik demi tercukupinya bahan pangan?. Kajian ini akan memfokuskan pembahasan tentang konsep islam dalam pemenuhan kebutuhan pangan masyarakat secara gamblang dan tuntas berdasarkan hadis-hadis nabi saw.

\section{Produktivitas Pertanian}


Produktivitas berarti kemampuan untuk menghasilkan sesuatu ${ }^{3}$. Lahan pertanian yang tadinya tidak dimanfaatkan, bisa produktif dengan diolah dan ditanami, sehingga menghasilkan hasil panen yang bisa dikomsumsi sebagai makanan. Sedangkan produksi adalah banyaknnya produk usaha tani yang diperoleh dalam rentang waktu tertentu. Satuan yang banyak digunakan adalah ton per tahun atau kg per tahun, tergantung dari potensi hasil setiap jenis komoditas. Islam adalah pedoman dalam kehidupan sehari-hari yang turun dari Allah Swt, Sang Pencipta manusia, sangat menghargai dan mendorong produktivitas manusia dalam menjalani kehidupannya sehari-hari, Rasulullah saw., bersabda :

Artinya:

Dari Ibnu 'Umar ra dari Nabi saw, ia berkata: "Sesungguhnya Allah mencintai orang yang beriman yang berkarya (produktif menghasilkan berbagai kebaikan) " H.R. Thabrani dalam Al Kabir, juga oleh Al Bayhaqi.

Salah satu karya produktif umat yang dianjurkan oleh Rasulullah saw. adalah mencari rezeki lewat usaha pertanian, seperti sabdanya:

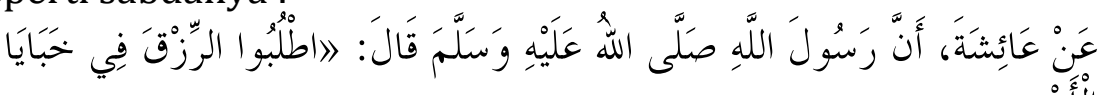

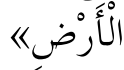

Artinya:

Dari Aisyah ra. Berkata : Rasulullah saw pernah bersabda : "Galilah rizki dari celah-celah (perut) bumi." (HR. Ahmad)

3 Kamus Lengkap Bahasa Indonesia, Penerbit Ketaping Surabaya, tt, halaman 467 . 
Hadis di atas mengandung pengertian bahwa islam menuntut umat manusia agar mengusahakan sebaik mungkin lahan yang ada diseluruh permukaan bumi untuk dioptimalkan, agar lahan tersebut tidak menjadi terlantar dan kurang produktif. Dalam dunia pertanian, tujuan yang ingin dicapai adalah hasil panen yang maksimal. Untuk mendapatkan hasil yang maksimal, perlu dibuatkan perencanaan yang matang mulai dari proses pengolahan tanah, pembibitan, penanaman, perawatan, pemupukan, pengendalian hama dan penyakit tanaman hingga pada saat pengelolaan hasil panen. Perencanaan ini dikenal sebagai metode intensifikasi pertanian, yaitu metode peningkatan produksi pertanian yang dilakukan dengan memperhatikan dan mengoptimalkan setiap proses tahapannya dengan baik dan maksimal.

Langkah pertama yang harus dilakukan adalah pengolahan lahan pertanian. Lahan pertanian harus diolah terlebih dahulu sebelum ditanami. Mengolah tanah terlebih dahulu dimaksudkan agar benih yang ditanam nantinya bisa tumbuh dengan subur dan memberikan hasil panen yang melimpah. Beberapa cara pengolahan tanah yang baik antara lain land clearing 4 , penggaruan tanah, pemupukan, pembajakan tanah dan teknik konversi ${ }^{5}$.

Lahan yang sudah diolah selanjutnya ditanami benih. Benih yang dipilih haruslah berasal dari indukan yang unggul agar hasil panen yang diharapkan bisa optimal. Benih unggul dan bermutu memiliki beberapa keunggulan seperti daya

4 Pembersihan lahan yang dilakukan secara manual dengan menggunakan alat sederhana seperti cangkul, parang, sabit dan lain sebagainya.

5 Pengolahan tanah dengan cara membuat alur atau strip pada titik penanaman saja.

TAHDIS Volume 10 Nomor 2 Tahun 2019 
tumbuhnya baik, daya tumbuhnya homogen dan produktivitas tinggi serta resisten terhadap hama dan penyakit.

Setelah benih ditanam, maka perawatan harus dilakukan dengan baik dan cermat. Seorang petani harus mengontrol setiap harinya. Aktivitas pengontrolan dilakukan seperti mengusahakan irigasi jika tanaman membutuhkan air, mengamati tanaman apakah ada serangan hama atau penyakit tanaman, memberikan pupuk pada saat dibutuhkan dan menyiangi jika ada gulma yang tumbuh disela-sela tanaman, serta melakukan pemangkasan daun atau ranting pada tanaman-tanaman tertentu untuk memastikan tanaman tersebut bisa memproduksi hasil panen yang maksimal.

Hasil panen harus dikelolah dengan baik. Hal ini dikarena bahan pertanian mudah rusak dan memiliki umur simpan yang pendek jika dibiarkan begitu saja. Beberapa komoditas tertentu harus segera didistribusikan kepada konsumen dengan cara dijual langsung ke penadah atau dibawa ke pasar. Adapula komoditas yang bisa diawetkan dengan cara dikeringkan, agar kadar airnya berkurang dan mikroba perusak dapat mati dan komoditas tersebut bisa disimpan beberapa bulan sebagai persediaan.

Metode lain yang dapat digunakan untuk meningkatkan produktivitas pertanian adalah metode diversifikasi produk pertanian. Diversifikasi pertanian merupakan upaya peningkatan produksi pertanian dengan menanam beberapa jenis tanaman. Tujuannya untuk menghindari ketergantungan hanya dari satu jenis tanaman pertanian saja. Dengan demikian, tanaman lain yang berpotensi juga lebih dikenal oleh masyarakat. Cara diversifikasi pertanian adalah dengan penanaman berbagai jenis komoditas tanaman dalam satu lahan pertanian. Keuntungan yang didapat akan berlipat ganda 
pada saat panen karena dapat menghasilkan berbagai jenis tanaman sekaligus.

Metode selanjutnya yang bisa dilakukan dalam rangka peningkatan produktivitas pertanian adalah pembangunan infrastruktur pertanian. Hal ini sudah sangat mendesak untuk dilakukan mengingat bahwa lahan hanya bisa produktif jika ditunjang oleh sarana dan prasarana pertanian yang baik. Sarana yang dimaksud berupa alat-alat pertanian, seperti bajak, traktor, cangkul, alat penyemprot, alat pemanen dan kendaraan untuk pengangkutan hasil pertanian. Sedangkan prasarana berupa instalasi irigasi pertanian (bendungan, saluran irigasi, pintu air dan pompa), jalan produksi dan pasar tradisional sebagai tempat penjualan hasil pertanian.

\section{Pola Distribusi Hasil Pertanian}

Alur pemasaran hasil pertanian merupakan proses distribusi hasil pertanian, dari petani kepada konsumen. Petani yang telah memanen lahannya, tentunya harus segera didistribusikan kepada konsumen, untuk mendapatkan hasil dari kerja kerasnya selama ini. Banyak cara mereka lakukan untuk mendistribusikan hasil pertaniannya, namun secara umum, pola distribusi hasil pertanian dapat dikelompokkan menjadi tiga metode, yakni metode langsung, metode tidak langsung dan metode ekspor.

Metode langsung dilakukan oleh petani dengan cara bekerjasama dengan mitra tertentu (seperti hotel, restoran, warung makan dan rumah sakit atau rumah tangga). Metode ini sangat efektif dan efisien karena petani telah mendapatkan pelanggan sebelum memulai usaha pertaniannya. Namun demikian, petani tersebut harus menjaga kualitas produknya demi keberlanjutan kontrak. Kekurangan dari metode ini 
adalah harga yang menjadi kesepakatan lebih murah daripada harga pasaran.

Metode tidak langsung merupakan metode yang paling lazim digunakan oleh petani-petani yang ada dipelosok. Metode ini mereka ambil sebagai langkah paling mudah karena mereka mengalami keterbatasan arus informasi dan komunikasi, jaringan bisnis, sarana transportasi dan keterbatasan pengetahuan sehingga mereka lebih memilih untuk menjual hasil pertaniannya kepada pihak kedua (pedagang pengumpul, koperasi, atau pengecer) kemudian pihak kedua menjual langsung atau mendistribusikan lagi kepada pedagang di pasar trandisional.

Metode pola distribusi yang terakhir adalah eksportir. Metode ini dilakukan oleh pengusaha pertanian yang berskala besar. Mereka memiliki manajemen yang mengatur setiap proses dari awal hingga produk sampai ke tangan calon konsumen di luar negeri. Untuk melakukan ekspor ke luar negeri, tidaklah mudah. Banyak persyaratan yang harus dilalui, seperti uji mutu pangan, sertifikasi organik, dan sebagainya. Selain itu, produk yang akan diekspor juga mempertimbangkan waktu dan jarak, mengingat perjalanan biasanya memakan waktu yang sangat lama.

Dalam Islam, dalil yang menekankan tentang distribusi pangan, terdapat dalam hadis tentang larangan menimbun barang. Rasulullah saw, bersabda :

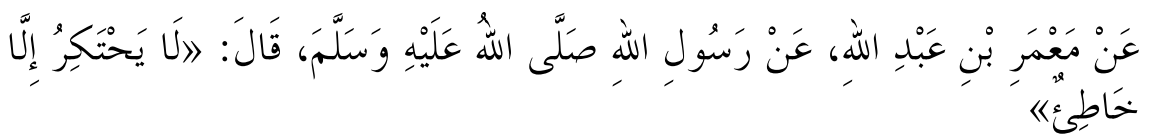
Artinya:

"Dari Ma'mar ia berkata, Rasulullah saw bersabda : Barangsiapa yang menimbun barang, maka ia bersalah (berdosa)" (HR. Muslim). 
Menimbun atau memonopoli adalah tindakan menyimpan barang dalam waktu tertentu dengan tujuan memperoleh keuntungan yang besar. Menimbun akan merusak pasar karena barang yang tersedia mengalami kelangkaan yang mengakibatkan lonjakan harga secara drastis. Tindakan ini sangat jelas dilarang dalam islam karena merugikan banyak orang.

Berdasarkan banyak hadis yang menjelaskan tentang haramnya perilaku penimbunan yang berkaitan dengan bahan makanan, sedangkan penimbunan barang selain bahan makanan lainnya tidaklah haram. Namun pendapat yang kuat adalah diharamkannya menimbun barang yang menjadi hajat orang banyak karena akan menyusahkan mereka jika terjadi kelangkaan. Pelajaran yang diambil dari diharamkannya penimbunan adalah agar jangan sampai sifat tamak sebagian orang dalam suatu masyarakat menyebabkan kesengsaraan dan kesulitan banyak orang. Sebab, islam adalah agama yang bertujuan memberikan dan merealisasikan kemaslahatan bagi masyarakat banyak serta mencegah dari kemudharatan.

\section{Pola konsumsi bahan pangan}

Pemenuhan kebutuhan pangan yang cukup dan terjangkau oleh seluruh penduduk adalah salah satu tujuan utama pembangunan nasional. Dengan terpenuhinya kebutuhan pangan maka penduduk dapat hidup sejahtera dan melakukan aktivitas keseharian dengan baik. Konsumsi bahan pangan masyarakat Indonesia adalah beras, jagung dan umbiumbian. Berdasarkan data statistik konsumsi pangan tahun 2018, beras menempati urutan pertama terbanyak dikonsumsi, yaitu sebanyak 80,641 kg/kapita/tahun. Kemudian tepung 
terigu 2,638 $\mathrm{kg} / \mathrm{kapita} /$ tahun dan ketiga adalah jagung sebanyak $1,534 \mathrm{~kg} / \mathrm{kapita} /$ tahun.

Dengan membaca angka konsumsi tersebut, maka terdapat gap yang cukup besar antara jumlah produksi dengan jumlah kebutuhan konsumsi. Tepung terigu sudah jelas kita impor, karena Negara kita tidak memproduksi gandum yang merupakan bahan baku terigu. Sedangkan beras dan jagung yang tumbuh subur di Negara kita, ternyata tidak mencukupi pula, sehingga harus impor dari Negara seperti Thailand dan Vietnam.

Dalam Islam, padahal Allah swt telah menjanjikan kecukupan rezeki bagi seluruh makhluknya, seperti dalam firmanNya :

Artinya:

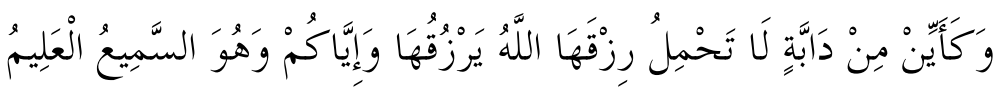

"Dan berapa banyak binatang yang tidak (dapat) membawa (mengurus) rezekinya sendiri. Allah-lah yang memberi rezeki kepadanya dan kepadamu dan Dia Maha Mendengar lagi Maha Mengetahui." (QS. Al Ankabut : 60).

Janji Allah swt. dalam ayat ini bersyarat, yaitu apabila segala petunjukNya diikuti dan dilaksanakan, apabila tugastugas memakmurkan bumi yang diberikan kepada manusia sebagai khalifah di muka bumi, dilaksanakan dengan baik, maka janji Allah swt. Akan melimpahkan rezeki kepada manusia. Akan tetapi apabila petunjuk Allah swt. tidak diikuti, perintah tidak dilaksanakan atau bahkan disalahgunakan seperti terjadinya pengelolaan bumi saat ini yang tidak memakai kaidah-kaidah pengelolaan bumi yang baik, misalnya sebagian penduduk dunia membuang-buang makanannya, sedangkan yang lain sampai pada tingkat kelaparan yang 
massif. Dan sesungguhnya Allah swt. Maha Mendengar dan Maha Mengetahui segala perbuatan manusia di dunia.

Organisasi PBB yang membidangi pertanian, Food and Agriculture Organization (FAO), mencatat bahwa jumlah makanan yang dibuang sebagai sisa-sisa makanan (waste) di negara-negara maju mencapai 222 juta ton per tahun, sedangkan total produksi pangan di Negara-negara di benua Afrika hanya berkisar total 230 juta ton per tahun. Bila negaranegara maju membuang makanannya dalam bentuk sisa-sisa makanan, lain halnya dengan negara-negara berkembang mengenai cara membuang makanannya, mereka lebih cenderung dalam hal menyia-nyiakan sumber daya lahan produksinya dalam berbagai bentuk inefficiency pra panen dan pasca panen. Lahan yang seharusnya berproduksi tinggi, tidak bisa optimal karena proses yang dilakukan tidak procedural.

Negara-negara berkembang juga memperparah ketidakcukupan bahan pangannya sendiri dengan cara bergantung pada bahan pangan impor, yang diproduksi oleh negara-negara maju, sedangkan potensi yang ada di negaranya sendiri tidak dikembangkan atau diolah secara optimal. Padahal potensi negaranya sendiri jauh lebih besar jika dilakukan pengelolaan dengan maksimal. Seperti misalnya ketergantungan terhadap tepung terigu untuk membuat kue, padahal negara kita dianugerahkan berbagai macam tepung yang berasal dari produk local yang tidak kalah kualitasnya dengan tepung terigu, kita bisa memproduksi tepung-tepungan seperti tepung tapioka dari singkong, tepung maizena dari jagung, tepung beras dan sebagainya.

Dalam Islam, beberapa cara yang dapat dilakukan untuk memenuhi bahan pangan yang cukup bagi semua, yaitu pertama, kita dianjurkan untuk makan secukupnya dan tidak berlebih-lebihan hingga sampai menyiakan makanan dengan 
membuang makanan. Seperti dalam firman Allah Swt dalam Surah Al A'raf ayat 31, yang artinya, "Hai anak Adam, pakailah pakaianmu yang indah di setiap (memasuki) mesjid, makan dan minumlah, dan janganlah berlebih-lebihan. Sesungguhnya Allah tidak menyukai orang-orang yang berlebih-lebihan."

Kedua, sajian makanan yang kita hidangkan cenderung sendiri-sendiri dan tidak makan bersama-sama. Setiap orang makan dengan piringnya masing-masing, sehingga memperbesar peluang untuk menyisakan makanan untuk dibuang. Ketika makanan menjadi sisa, maka orang lain sudah pasti tidak mau memakannya. Di restoran-restoran, warungwarung makan, hingga di pesta-pesta atau hajatan, seringkali kita temui banyak makanan sisa-sisa yang terbuang. Bahkan sangat ironis sekali di lokasi pengungsian korban bencana alam, juga sering kita dapati makanan sisa terbuang di berbagai tempat. Padahal mereka dibantu untuk meringankan beban atas musibah yang menimpa, seharusnya mereka bisa peka bahwa setiap makanan yang diberikan dalam kotak-kotak merupakan donasi dari orang-orang yang peduli kepada mereka. Sehingga yang terjadi adalah ketika makanan ada tersedia, dia berlebih dan kemudian sebagiannya terbuang dalam bentuk sisa, dilain waktu tidak tersedia sama sekali.

Seharusnya pola makan sendiri-sendiri seperti ini harus mulai kita tinggalkan. Dalam islam, ini ada dasarnya dalam petunjuk Rasulullah saw. kita melalui hadis beliau ketika menjawab pertanyaan sahabatnya : "Ya Rasulullah, kami makan tetapi tidak kenyang". Dia (Rasulullah) bertanya : "Barangkali kamu makan sendiri-sendiri?" Mereka menjawab : "Ya". Rasulullah berkata : "Jika kalian makan makanan bersama-sama dengan menyebut nama Allah, kalian akan mendapatkan keberkahan di dalamnya". (HR. Sunan Abu Dawud). Bukan 
hanya makanan sisa yang didapat jika kita makan sendirisendiri, tetapi juga kehilangan keberkahan.

Ketiga, jangan memaksakan mengimpor bahan pangan. Ketika bahan pangan kita paksakan untuk diimpor, maka produksi bahan makanan diwilayah kita akan menjadi tersaingi dan merusak harga pasar. Selain itu bahan makanan yang diimpor juga akan mahal (karena termasuk ongkos angkut). Berbagai macam masalah juga terjadi, seperti kelangkaan persediaan bahan pangan akan terjadi, misalnya faktor alam, maupun faktor manusianya - seperti ketimpangan dalam perdagangan global. Ketika kita sudah bergantung dengan bahan pangan impor dan suatu waktu bahan pangan tersebut mengalami kelangkaan, maka kita akan bersaing untuk mendapatkan makanan yang sama dengan Negara lain di dunia yang juga mengimpor bahan pangan yang sama. Hal ini juga diperparah jika kita tidak memproduksinya bahan pengganti, maka peluang terjadinya ketidakcukupan bahan pangan dalam memenuhi kebutuhan kita itu menjadi lebih besar.

Dalam hadis, lebih spesifiknya tersirat bahwa makanlah makanan yang terdekat denganmu. Makanan yang dekat dengan lingkungan sekitar kita, lebih jauh lagi, makanlah makanan yang kita produksi sendiri di Negara kita dengan sumber daya alam yang dimiliki, jangan memaksakan mengimpor bahan makanan dan akan akhirnya bisa mengalami ketergantungan.

Kecukupan bahan pangan yang kita konsumsi sejatinya merupakan tentang apa yang kita makan dan bagaimana cara kita memakannya. Apabila telah mengikuti petunjukNya dan sunnah nabiNya, maka dari situlah berlaku jaminanNya bahwa tersedia rezeki yang cukup bagi seluruh makhlukNya di muka bumi ini. 


\section{Kesimpulan}

Islam adalah agama yang sempurna dan mengatur seluruh aspek kehidupan manusia. Salah satu aspek yang diatur adalah persoalan kecukupan bahan pangan bagi seluruh penduduk dunia. Penduduk dunia saat ini berjumlah 7.7 miliar, tentunya bukan angka yang kecil untuk menyediakan bahan pangan. Persoalan bahan pangan terjadi karena adanya gap yang besar antara persediaan dan kebutuhan. Secara umum, persoalan kecukupan bahan pangan berawal dari manajemen penggunaan lahan. Lahan yang tidak digarap dengan konsepkonsep islam, maka akan kurang produktif untuk menghasilkan bahan pangan yang cukup untuk memenuhi kebutuhan manusia. Beberapa konsep yang bisa dilakukan untuk memakmurkan bumi antara lain intensifikasi pertanian, diversifikasi pertanian dan perbaikan sarana dan prasarana pertanian.

Dari sisi distribusi hasil pertanian, islam mengajarkan untuk tidak menimbun bahan pangan ketika terjadi kelangkaan. Bahan pangan harus terdistribusi baik sesuai dengan mekanisme pasar. Pola distribusi dari petani sebagai produsen hasil bumi hingga sampai kepada konsumen dapat dilakukan menggunakan tiga cara, yaitu distribusi langsung (petani langsung menjual hasil pertaniannya kepada konsumen), distribusi tidak langsung (petani penjual hasil pertaniannya kepada perantara/distributor, kemudian distributor menjual lagi kepada konsumen) dan pola distibusi ekspor (petani atau perusahaan menjual hasil pertaniannya ke luar negara).

Pola konsumsi bahan pangan juga diatur dalam islam. Pertama, makan secukupnya dan tidak berlebihan apalagi sampai membuang makanan. Kedua, disarankan untuk makan secara berjamaah untuk menghindari sisa-sisa makanan. Dan 
Ketiga, jangan memaksakan mengimpor bahan pangan. Kecukupan bahan pangan yang kita konsumsi sejatinya merupakan tentang apa yang kita makan dan bagaimana cara kita memakannya. Apabila telah mengikuti petunjukNya dan sunnah nabiNya, maka dari situlah berlaku jaminanNya bahwa tersedia rezeki yang cukup bagi seluruh makhlukNya di muka bumi ini. Sungguh janji Allah swt. adalah benar. 


\section{Daftar Pustaka}

Astawa, I. B., \& Sarmita, I. M. (2018). Geografi Penduduk.

Singaraja: Penerbit Rajagrafindo Persada.

Holisah, L. (2015). m.kiblat.net. Dipetik Desember 30, 2019, dari m.kiblat.net:

http://m.kblat.net/2015/02/06/islam-solusi-

ketahanan-pangan/

Iqbal, M. (2015). Watana The Mindset. Bogor: Startup Center.

Kementerian Agama Republik Indonesia. (2013). Al Qur'an

Terjemah Perkata, Asbabun Nuzul dan Tafsir bil Hadis.

Bandung: Penerbit Semesta Al Qur'an.

Kementerian Pendidikan dan Kebudayaan. (2007). Kamus

Besar Bahasa Indonesia. Jakarta.

Peraturan Menteri Pertanian, No.

25/Permentan/OT.140/2/2010.

Setiawan, I. (2012). Agribisnis Kreatif, Pilar Wirausaha Masa

Depan, Kekuatan Dunia Baru Menuju Kemakmuran Hijau. Jakarta: Penerbit Swadaya.

Worldometers. (t.thn.). Dipetik 12 31, 2019, dari

www.wolrdometers.info 